\title{
PENGARUH KUALITAS PELAYANAN AKADEMIK TERHADAP KEPUASAN MAHASISWA PADA SEKOLAH TINGGI ILMU EKONOMI PRABUMULIH
}

\section{THE INFLUENCE OF THE ACADEMIC QUALITY OF SERVICE TOWARDS THE SATISFACTION OF STUDENTS AT THE HIGH SCHOOL OF ECONOMICS, PRABUMULIH}

\author{
Susianti \\ Sekolah Tinggi Ilmu Ekonomi Prabumulih \\ sy40062@gmail.com
}

\begin{abstract}
Evaluation of service quality at Prabumulih College of Economics is needed to find out what is actually expected and perceived by students with what has been offered. This study aims to determine the effect of academic service quality on student satisfaction at the Prabumulih College of Economics. The method used in this study is a survey method. The data collected consists of primary data and secondary data. Primary data obtained through the interview method that is equipped with a questionnaire that has been prepared. Secondary data were obtained from related companies, as well as several library sources in the form of journals and books relating to this research. And the method used in this research is survey method. The data collected consists of primary data and secondary data. Primary data obtained through the interview method that is equipped with a questionnaire that has been prepared. In this study, what will be analyzed is the effect of service quality consisting of 1) tangible (direct evidence) including physical facilities, equipment, employees, and communication facilities; 2) reliability, which is the ability to provide the promised service immediately, accurately and satisfactorily; 3) responsiveness (responsiveness), namely the desire of staff to help customers and provide services responsively; 4) assurance, including knowledge, competence, courtesy, and trustworthiness of staff, free from danger, risk or doubt; and 5) empathy (empathy), including ease in establishing relationships, good communication, personal attention, and understanding of the individual needs of customers. The results showed that physical evidence, reliability, responsiveness, assurance, concern and student satisfaction had a positive and significant effect on student satisfaction.
\end{abstract}

Keywords: Quality of Service, the Satisfaction of College Students

\begin{abstract}
ABSTRAK
Evaluasi kualitas jasa di Sekolah Tinggi Ilmu Ekonomi Prabumulih diperlukan untuk mengetahui apa yang sebenarnya selama ini diharapkan dan dipersepsikan oleh mahasiswa dengan yang telah ditawarkan. Penelitian ini bertujuan untuk mengetahui Pengaruh Kualitas Pelayanan Akademik Terhadap Kepuasan Mahasiswa Pada Sekolah Tinggi Ilmu Ekonomi Prabumulih. Metode yang digunakan dalam penelitian ini adalah metode survey. Data yang dikumpulkan terdiri dari data primer dan data sekunder. Data primer diperoleh melalui metode wawancara yang dilengkapi dengan kuisioner yang telah disiapkan. Data sekunder diperoleh dari perusahaan yang terkait, serta beberapa
\end{abstract}


sumber pustaka baik berupa jurnal maupun buku yang berhubungan dengan penelitian ini. Metode yang digunakan dalam penelitian ini adalah metode survey. Data yang dikumpulkan terdiri dari data primer dan data sekunder. Data primer diperoleh melalui metode wawancara yang dilengkapi dengan kuisioner yang telah disiapkan. Dalam penelitian ini, yang akan dianalisis adalah pengaruh kualitas pelayanan yang terdiri dari 1) tangible (bukti langsung) mencakup fasilitas fisik, perlengkapan, pegawai, dan sarana komunikasi; 2) reliability (reliabilitas), yaitu kemampuan memberikan pelayanan yang dijanjikan dengan segera, akurat, dan memuaskan; 3) responsiveness (daya tanggap), yaitu keinginan staf membantu para pelanggan dan memberikan layanan dengan tanggap; 4) assurance (jaminan), mencakup pengetahuan, kompetensi, kesopanan, dan sifat dapat dipercaya yang dimiliki staf, bebas dari bahaya, resiko, atau keragu-raguan; dan 5) empathy (empati), meliputi kemudahan dalam menjalin relasi, komunikasi yang baik, perhatian pribadi, dan pemahaman atas kebutuhan individu para pelanggan. Simpulan, bukti fisik, keandalan, daya tanggap, jaminan, kepedulian dan kepuasan mahasiswa berpengaruh yang positif dan signifikan terhadap kepuasan mahasiswa.

Kata Kunci : Kualitas Pelayanan, Kepuasan Mahasiswa

\section{PENDAHULUAN}

Dalam lingkungan perguruan tinggi konsep tentang pelanggannya belum sepenuhnya terdefenisikan. Hal ini menyatakan institusi ini menjadi sulit untuk menetapkan sudut pandang dalam hal pelayanan kepada pelanggan. Ada beberapa literatur yang memperlihatkan berbagai macam kelompok yang dapat dikategorikan sebagai pelanggan institusi sebuah perguruan tinggi, yaitu mahasiswa, karyawan, keluarga dan masyarakat. Akan tetapi salah satu dari kelompok yang telah disebutkan di atas telah ditetapkan dengan penuh pertimbangan bahwa deskripsi pelanggan dari sebuah perguruan tinggi adalah mahasiswa dari perguruan tinggi itu sendiri.

Selama ini penilaian kualitas jasa perguruan tinggi lebih menekankan pada penilaian yang dilakukan oleh pihak lain (misalnya Badan Akreditasi Nasional), padahal titik sentral pengelolaan perguruan tinggi itu sendiri adalah mahasiswa sebagai pelanggan utamanya. Oleh karena itu, sangat penting bagi pengelola sekolah tinggi dan perguruan tinggi untuk mendapatkan umpan balik (feedback) tentang kualitas jasa yang diberikan dari sudut pandang penilaian mahasiswa itu sendiri. Seperti yang disampaikan oleh Kotler (2012) bahwa kualitas harus dimulai dan berakhir pada pelanggan.

Penelitian terhadap tingkat kepuasan konsumen dalam ranah bisnis telah banyak dilakukan. Telah banyak penelitian yang mencoba mengidentifikasi hubungan antara kualitas jasa dengan tingkat kepuasan pelanggan, bahkan sampai pada tingkatan loyalitas konsumen. Akan tetapi didalam lembaga pendidikan tinggi sendiri masih sulit untuk menemukan penelitian yang membahas tentang topik ini. Hal ini disebabkan karena pada umumnya penelitian semacam itu lebih banyak dilakukan secara internal dalam pengambilan keputusan oleh manajemen.

Namun Konsep dan hasil-hasil penelitian dari peneliti sebelumnya terhadap berbagai organisasi jasa dapat dimanfaatkan dalam memberi arah dan gambaran dalam memahami tingkat kualitas jasa dan kepuasan akan jasa yang dirasakan oleh mahasiswa Sekolah Tinggi Ilmu Ekonomi Yayasan 
Pendidikan Prabumulih, adapun jumlah baru mahasiswa baru berdasarkan tahun akademik dari tahun 2014 - 2016 dapat dilihat pada tabel 1.1 berikut:

\section{Tabel 1 Jumlah Mahasiswa Baru} Tahun Akademik 2014 - 2017

\begin{tabular}{ccc}
\hline $\begin{array}{c}\text { Tahun } \\
\text { Akademik }\end{array}$ & $\begin{array}{c}\text { Mahasiswa } \\
\text { Reguler }\end{array}$ & $\begin{array}{c}\text { Mahasiswa } \\
\text { Transisi }\end{array}$ \\
\hline $2014-2015$ & 113 & 5 \\
\hline $2015-2016$ & 58 & 3 \\
\hline $2017-2018$ & 66 & 5 \\
\hline
\end{tabular}

Sumber : BAAK STIE Prabumulih, 2018

Tabel 1 di atas menunjukkan jumlah mahasiswa baru Sekolah Tinggi Ilmu Ekonomi Prabumulih untuk tahun akademik 2014 sampai dengan 2017, yaitu dari tahun akademik 2014 mengalami penurunan jumlah mahasiswa baru dari 113 orang mahasiswa cukup drastis turun menjadi 58 orang mahasiswa, tapi pada tahun 2017 kembali mengalami kenaikan hanya sebesar 66 orang mahasiswa.

Kualitas suatu perguruan tinggi sangat ditentukan oleh mutu pelayanan yang diberikan, dimana pelayanan yang bermutu dapat diindetifikasi melalui kepuasan pelanggan dalam hal ini adalah mahasiswa. Bagi sebuah perguruan tinggi kepuasan layanan lebih diorientasikan kepada mahasiswa karena mahasiswa merupakan pelanggan primer dari perguruan tinggi. Perguruan tinggi sebagai industri jasa harus terus memikirkan pentingnya pelayanan pelanggan secara lebih matang, kerena kini semakin disadari bahwa pelayaan dan kepuasaan pelanggan merupakan aspek vital dalam rangka bertahan dalam bisnis.

Meningkatnya kuantitas perguruan tinggi ini menuntut masingmasing lembaga pendidikan harus memperhatikan mutu pendidikan dan kelembagaan sehingga mampu serta unggul dalam persaingan tersebut. Di sisi lain perguruan tinggi dituntut untuk menggali dan meningkatkan segala aspek pelayanan yang prima akan berimplikasi pada peningkatan citra perguruan tinggi dan sebaliknya pelayanan yang buruk akan dan memenangkan persaingan (Tjiptono, 2004).

Evaluasi kualitas jasa di Sekolah Tinggi Ilmu Ekonomi Prabumulih diperlukan untuk mengetahui apa yang sebenarnya selama ini diharapkan dan dipersepsikan oleh mahasiswa dengan yang telah ditawarkan. Ketidakpuasan sering terjadi hanya karena disebabkan oleh perbedaan antara apa yang ditawarkan dengan apa yang diharapkan oleh pelanggan. Apa yang dianggap berkualitas oleh pihak Yayasan belum tentu berkualitas dan memuaskan bagi mahasiswa.

Banyak pakar dan organisasi yang mencoba mendefinisikan kualitas berdasarkan sudut pandangnya masingmasing. Beberapa diantaranya adalah sebagai berikut:

1. Performance to the standard expected by the cutomer

2. Peeting the customer's needs the first time and every time

3. Providing our customers with products and services that consistently meet their needs and expectations.

4. The unyielding and continuing effort by everyone in an organization to understand, meet, and exceed the needs of its customers

5. A pragmatic system of continual improvement, A way to successfully organize man and machines.

Meskipun tidak ada definisi mengenai kualitas yang diterima secara universal, namun dari antara definisidefinisi tersebut terdapat beberapa kesamaan, antara lain sebagai berikut:

1. kualitas meliputi usaha memenuhi atau melebihi harapan pelanggan 
2. kualitas mencakup produk, jasa, manusia, proses dan lingkungan.

3. kualitas merupakan kondisi yang selalu berubah (apa yang dianggap merupakan kualitas saat ini mungkin dianggap kurang berkualitas pada masa mendatang).

Dengan berdasarkan elemenelemen tersebut, Goetsch et al. (2014) membuat definisi mengenai kualitas dengan cakupan yang lebih luas. Definisi tersebut yaitu: "Kualitas merupakan suatu kondisi dinamis yang berhubungan dengan produk, jasa, manusia, proses dan lingkungan yang memenuhi atau melebihi harapan."

Dimensi yang digunakan untuk mengukur kepuasan konsumen beranekaragam yang diantaranya adalah dimensi yang dikemukakan oleh David Garvin untuk kualitas produk (barang), sementara untuk mengukur kualitas jasa dapat dilakukan dengan menggunakan model SERVQUAL (service quality) yang dikembangkan oleh Parasuraman dan kawan-kawan dalam penelitiannya terhadap beberapa sektor jasa.

Dari penelitiannya, Zeithaml et al. (2012) berhasil mengidentifikasi lima kelompok karakteristik yang digunakan oleh pelanggan dalam mengevaluasi kualitas jasa, yakitu:

1. Tangibles (bukti fisik), yaitu suatu penampilan fisik yang membuat suatu layanan berlangsung dengan lebih baik meliputi fasilitas fisik, perlengkapan, pegawai, dan saranan komunikasi.

2. Reliability (keandalan), yaitu seberapa jauh anda bisa memenuhi apa yang anda janjikan atau tawarkan dengan segera, akurat, terpercaya, dan memuaskan bagi pelanggan.

3. Responsiveness (ketanggapan), yaitu kemampuan memenuhi permintaan pelanggan dengan cepat dan tepat sesuai dengan perkembangan lingkungan usaha..

4. Assurance (jaminan), yaitu kemampuan atau sumber daya yang dimiliki yang akan menentukan kemampuan memenuhi apa yang ditawarkan atau dijanjikan sehingga dapat menimbulkan kepercayaan tanpa menimbulkan karaguan pelanggan terhadap pelayanan, yang mencakup kemampuan, kesopanan, dan sifat dapat dipercaya yang dimiliki para staf; bebas dari bahaya, resiko atau keragu-raguan.

5. Empathy (empati), yaitu upaya untuk memenuhi kebutuhan dan keinginan sang pelanggan. Adanya perhatian yang lebih bersifat pribadi kepada pelanggan, melakukan kontak, hubungan, dan komunikasi yang baik dengan pelanggan merupakan wujud empati kepada pelanggan.

Pada hakekatnya pengukuran kualitas suatu jasa atau produk hampir sama dengan pengukuran kepuasan pelanggan yakitu ditentukan oleh variable persepsi pelanggan atas layanan yang nyata mereka terima (perceived service) dengan layanan yang sesungguhnya diharapkan (expected performance). Singkat kata kualitas jasa dapat didefinisikan sebagai seberapa jauh perbedaan antara kenyataan dan harapan pelanggan atas jasa layanan yang mereka terima Zeithaml et al. (2012).

Pada hakikatnya tujuan bisnis adalah untuk menciptakan dan mempertahankan para pelanggan. Dalam pendekatan TQM (total quality manajemen), kualitas ditentukan oleh pelanggan.Oleh karena itu semua usaha manajemen dalam meningkatkan suatu kualitas diarahkan pada satu tujuan utama yakitu terciptanya kepuasan pelanggan. Apapun yang dilakukan oleh manajemen tidak akan ada gunanya bila akhirnya tidak 
menghasilkan peningkatan kepuasan konsumen. Kepuasan pelanggan dapat memberikan beberapa manfaat, diantanya (Tjiptono, 2004) :

1. Hubungan antara perusahaan dan pelanggannya dapat menjadi harmonis

2. Memberikan dasar yang baik bagi pembelian ulang

3. Dapat mendorong terciptanya loyalitas pelanggan

4. Membentuk suatu rekomendasi dari mulut ke mulut (words-of-mouth) yang menguntungkan bagi perusahaan.

5. Reputasi perusahaan menjadi baik di mata pelanggan.

6. Laba yang diperoleh dapat meningkat.

Kepuasan pelanggan sendiri tidak mudah didefinisikan. Ada berbagai macam pengertian yang diberikan oleh para pakar bisnis tentang hal ini. Menurut Kotler (2014) kepuasan adalah tingkat perasaan seseorang setelah membandingkan kierja (atau hasil) yang ia rasakan dibandingkan dengan harapannya. Wilkie mendefinisikan kepuasan sebagai suatu tanggapan emosional pada evaluasi terhadap pengalaman konsumsi suatu produk atau jasa.

Engel (2011) menyatakan bahwa kepuasan pelanggan merupakan evaluasi purnabeli dimana alternatif yang dipilih sekurang-kurangnya sama atau melampaui harapan pelanggan, sedangkan ketidakpuasan timbul apabila hasil (outcome) tidak memenuhi harapan. Apabila kinerja dibawah harapan, maka pelanggan akan kecewa. Bila kinerja sesuai dengan harapan, pelanggan akan puas.dan tentunya bila kinerja melebihi harapan, maka pelanggan juga akan merasa sangat puas.

Harapan pelanggan ini sendiri dibentuk oleh pengalaman masa lampau, komentar dari kerabatnya, janji dan informasi dari pemasar maupun saingan. Konsep kepuasan pelanggan dapat dilihat pada diagram dibawah ini (Rangkuti, 2012)

Ada beberapa hal yang perlu dicermati tentang perguruan tinggi sebagai sebuah jasa. Hal tersebut adalah karakteristik jasa perguruan tinggi, antara lain:

1. Perguruan tinggi termasuk kedalam kelompok jasa murni, dimana pemberian jasa yang dilakukan didukung alat kerja atau sarana pendukung semata. Contoh: ruangan kelas, kursi, meja, bukubuku, dan sebagainya.

2. Jasa yang diberikan membutuhkan kehadiran pengguna jasa (mahasiswa), yang dalam ini pelanggan yang mendatangi lembaga pendidikan tersebut untuk mendapatkan jasa yang diinginkan (meski dalam perkembangannya ada juga yang menawarkan program universitas terbuka, kuliah jarak jauh, dll)

3. Penerima jasanya adalah orang, jadi merupakan pemberian jasa yang berbasis orang atau dalam jasa biasa disebut sistem kontak tinggi, yakitu hubungan antara pemberi jasa dengan pelanggan tinggi. Pelanggan dan penyedia jasa terus berinteraksi selama proses pemberian jasa berlangsung. Dengan kata lain, untuk menerima jasa, pelanggan harus menjadi bagian dari sistem jasa tersebut.

4. Hubungan dengan pelanggan berdasarkan hubungan keanggotaan (member relationship) di mana pelanggan telah menjadi anggota lembaga pendidikan tertentu). Sistem pemberian jasanya dilakukan secara terus-menerus dan teratur 
Sebagai perusahaan berbentuk jasa, aspek manajemen (pengelola) dan sumber daya manusia juga merupakan hal terpenting dalam mengelola sebuah perguruan tinggi. Untuk menghasilkan kualitas yang baik, sebuah perguruan tinggi mesti membarenginya dengan peningkatkan kualitas kinerja semua SDM yang ada. Di perguruan tinggi negeri (PTN) sendiri, pemegang utama kendali manajemen adalah rektor yang tentunya perlu didukung oleh pejabat struktural, mulai dari tingkat pembantu rektor hingga dekan dan ketua program studi serta semua staf yang ada. Pada PTN, terdapat dua jenis staf, yakitu: 1) staf akademik yang melakukan pekerjaan mengajar, meneliti, dan menjalankan layanan masyarakat, 2) staf pendukung yang meliputi pekerja profesional di bidang tertentu, staf administrasi, keamanan, teknis, dan lain-lain. Kesemuanya itu harus diupayakan terus-menerus dalam peningkatkan kualitas kinerjanya.

\section{METODE PENELITIAN}

\section{Waktu dan Wilayah Penelitian}

Penelitian ini akan dilaksanakan di Sekolah Tinggi Ilmu Ekonomi Prabumulih. Penelitian ini akan dilaksanakan pada bulan Maret sampai dengan bulan Oktober 2018. Penentuan lokasi dilakukan dengan sengaja (purposive) dengan pertimbangan bahwa Sekolah Tinggi Ilmu Ekonomi Prabumulih merupakan salah satu perguruan tinggi di kota Prabumulih dengan populasi yang cukup dan berasal dari dua jurusan dalam hal ini manajemen dan akuntansi.

\section{Populasi dan Sampel}

Populasi target dalam penelitian ini adalah mahasiswa yang ada di Sekolah Tinggi Ilmu Ekonomi Prabumulih berjumlah 270 populasi, metode penentuan sampel yang digunakan adalah purposive sampling dengan pertimbangan responden yang merupakan influencer/ decider. Jadi besarnya sampel yang digunakan dalam penelitian ini adalah sebanyak 73 Orang.

\section{Uji Instrumen dan Metode Analisis Uji Instrumen}

Uji Validitas yang diperlukan agar memperoleh instrument yang valid artinya instrument yang tepat untuk mengukur apa yang seharusnya diukur. Uji validitas dapat dilakukan dengan cara mengkoreelassikan skor tiap butir dengan skor total yang merupakan jumlah tiap skor pertanyaan yang dijawab oleh responden.

Reliabilitas adalah indeks yang menunjukkan sejauh mana suatu alat pengukuran dapat dipercaya atau dapat diandalkan dan sejauh mana hasil pengukuran tetap konsisten bila dilakukan pengukuran dua kali atau lebih terhadap gejala yang sama, dengan alat ukur yang sama (Singarimbun, 2013). Hasilnya ditunjukkan oleh sebuah indeks yang menunjukkan seberapa jauh sebuah alat ukur dapat diandalkan

\section{Analisis Regresi Berganda}

Berdasarkan permasalahaan hipotesis yang diajukan, alat teknis analisis statika

yang digunakan adalah analisi regresi linier sederhana dan berganda sehingga metode analisis yang digunakan dalam penelitian ini adalah sebagai berikut:

$$
\begin{aligned}
& \mathrm{Y}=\mathrm{a}+\mathrm{b}_{1} \mathrm{X}_{1}+\mathrm{b}_{2} \mathrm{x}_{2}+\mathrm{b}_{3} \mathrm{X}_{3}+\mathrm{b}_{4} \mathrm{X}_{4}+ \\
& \mathrm{b}_{5} \mathrm{x}_{5}+\mathrm{e} \\
& \text { Dimana } \\
& \mathrm{Y} \quad=\text { Kepuasan Mahasiswa } \\
& \mathrm{a} \quad=\text { Konstanta } \\
& \mathrm{b}_{1} \mathrm{~b}_{2} \quad=\text { Koefesien Regresi } \\
& \mathrm{x}_{1} \quad=\text { Reliability } \\
& \mathrm{x}_{2} \quad=\text { Responsiveness } \\
& \mathrm{x}_{3} \quad=\text { Empathy } \\
& \mathrm{x}_{4} \quad=\text { Assurancee } \\
& \mathrm{x}_{5} \quad=\text { Tangibles }
\end{aligned}
$$


e $=$ Error term (Kesadaran pengganggu yang dalam perhitungan nilainya diasumsikan 0 (nol).

\section{Uji serempak ( Uji F )}

Menurut Abdurahman (2011)

untuk mengetahui aapakah variabel bebas secara bersama-sama berpengaruh signifikan terhadap variabel terkaait uji $\mathrm{F}$ dengan asumsi:

1. Apabila Sig. $\mathrm{F}<\alpha(0,05)$ maka Ho ditolak yang berarti ada pengaruh yang

signifikan variabel independent secara bersama-sama terhadap variabel dependent.

2. Apabila Sig. $\mathrm{F}>\alpha(0,05)$ maka Ho diterima yang berarti tidak ada pengaruh yang signifikan variabel independent secara bersama-sama terhadap variabel dependent.

\section{Uji Parsial (Uji t)}

Untuk mengetahui apakah variabel bebas secara parsial berpengaruh signifikan terhadap variabel terkait uji t dengan asumsi.

1. Apabila Sig. $\mathrm{t}<\alpha(0,05)$ maka Ho ditolak yang berarti ada pengaruh yang signifikan variabel independent secara parsial terhadap variabel dependent.

2. Apabila Sig. $t>\alpha(0,05)$ maka Ho diterima yang berarti tidak ada pengaruh yang signifikan variabel independent secara bersama-sama terhadap variabel dependent.

\section{Koefisien Determinasi (Uji R2)}

Uji koefisien determinasi (Uji R2) dimaksudkan untuk mengetahui tingkat ketepatan baik dalam analisa regresi dimana hal yang ditunjukkan oleh besarnya koefisien determinasi (Uji R2) antara 0 (nol) dan 1 (satu). Koefisien determinasi (Uji R2) nol variable independen sama sekali tidak berpengaruh terhadap variabel dependen. Selain itu koefisien determinasi (Uji R2) dipergunakan untuk mengetahui prosentase perubahan variabel tidak bebas (Y) yang disebabkan oleh variable bebas. Dan uji ini digunakan untuk mengetahui seberapa jauh proporsi variasi dependen (setiaji, 2012: 29).

\section{HASIL DAN PEMBAHASAN Hasil Analisis Data Uji Validitas}

Pengujian validitas dilakukan dengan menggunakan metode Analisis korelasi. Perhitungan dilakukan dengan bantuan program SPSS. Nilai signifikansi yang berada di bawah 0,05 menunjukkan sebagai item yang valid. Pengujian validitas selengkapnya dapat dilihat pada Tabel berikut ini:

Tabel 2 Hasil Uji Validitas Variabel Tangible (X1)

\begin{tabular}{cccc}
\hline No & $\mathrm{r}_{\text {hitung }}$ & $\mathrm{r}_{\text {tabel }}$ & Keterangan \\
\hline 1 & 0,577 & 0,317 & Valid \\
\hline 2 & 0,716 & 0,317 & Valid \\
\hline 3 & 0,888 & 0,317 & Valid \\
\hline 4 & 0,489 & 0,317 & Valid \\
\hline 5 & 0,864 & 0,317 & Valid \\
\hline
\end{tabular}

Sumber: Data Primer Diolah, 2019

Tabel 3. Hasil Uji Validitas Variabel Reliabilty (X2)

\begin{tabular}{cccc}
\hline No & $\mathrm{r}_{\text {hitung }}$ & $\mathrm{r}_{\text {tabel }}$ & Keterangan \\
\hline 1 & 0,416 & 0,317 & Valid \\
\hline 2 & 0,518 & 0,317 & Valid \\
\hline 3 & 0,848 & 0,317 & Valid \\
\hline 4 & 0,527 & 0,317 & Valid \\
\hline 5 & 0,778 & 0,317 & Valid \\
\hline
\end{tabular}

Sumber: Data Primer Diolah, 2019

Tabel 4. Hasil Uji Validitas Variabel Responsiveness (X3)

\begin{tabular}{cccc}
\hline No & $\mathrm{r}_{\text {hitung }}$ & $\mathrm{r}_{\text {tabel }}$ & Keterangan \\
\hline 1 & 0,546 & 0,317 & Valid \\
\hline 2 & 0,640 & 0,317 & Valid \\
\hline 3 & 0,755 & 0,317 & Valid \\
\hline 4 & 0,495 & 0,317 & Valid \\
\hline 5 & 0,810 & 0,317 & Valid \\
\hline
\end{tabular}

Sumber: Data Primer Diolah, 2019 
Tabel 5 Hasil Uji Validitas Variabel Assurance (X4)

\begin{tabular}{cccc}
\hline No & $\mathrm{r}_{\text {hitung }}$ & $\mathrm{r}_{\text {tabel }}$ & Keterangan \\
\hline 1 & 0,589 & 0,317 & Valid \\
\hline 2 & 0,654 & 0,317 & Valid \\
\hline 3 & 0,825 & 0,317 & Valid \\
\hline 4 & 0,539 & 0,317 & Valid \\
\hline 5 & 0,823 & 0,317 & Valid \\
\hline
\end{tabular}

Sumber: Data Primer Diolah, 2019

Tabel 6 Hasil Uji Validitas Variabel Empathy (X5)

\begin{tabular}{cccc}
\hline No & $\mathrm{r}_{\text {hitung }}$ & $\mathrm{r}_{\text {tabel }}$ & Keterangan \\
\hline 1 & 0,554 & 0,317 & Valid \\
\hline 2 & 0,636 & 0,317 & Valid \\
\hline 3 & 0,866 & 0,317 & Valid \\
\hline 4 & 0,496 & 0,317 & Valid \\
\hline 5 & 0,853 & 0,317 & Valid \\
\hline
\end{tabular}

Sumber: Data Primer Diolah, 2019

Tabel 7 Hasil Uji Validitas Variabel Keputusan Konsumen (Y)

\begin{tabular}{cccc}
\hline No & $\mathrm{r}_{\text {hitung }}$ & $\mathrm{r}_{\text {tabel }}$ & Keterangan \\
\hline 1 & 0,548 & 0,317 & Valid \\
\hline 2 & 0,715 & 0,317 & Valid \\
\hline 3 & 0,866 & 0,317 & Valid \\
\hline 4 & 0,561 & 0,317 & Valid \\
\hline 5 & 0,849 & 0,317 & Valid \\
\hline
\end{tabular}

Sumber: Data Primer Diolah, 2019

Hasil uji validitas pada Tabel di atas dapat diketahui bahwa semua indikator berkorelasi signifikan dengan total skor, ditunjukan nilai rhitung > dari rtabel. Korelasi yang signifikan antara skor indikator dengan total skor menunjukan bahwa indikator yang digunakan baik dari variabel bebas (X) maupun dari variabel terikat (Y) dapat mengukur variabel yang diteliti, semua indikator yang digunakan untuk mengukur variabel-variabel yang digunakan dalam penelitian ini mempunyai nilai korelasi yang lebih besar dari 0,317. Dari hasil tersebut menunjukkan bahwa semua indikator tersebut adalah valid.

\section{Uji Reliabilitas}

Pengujian reliabilitas dalam penelitian ini adalah dengan menggunakan rumus Cronbach Alpha.
Hasil pengujian reliabilitas untuk masing-masing variabel yang diringkas pada tabel berikut ini:

Tabel 8 Hasil Pengujian Reliabilitas

\begin{tabular}{lll}
\hline \multicolumn{1}{c}{ Variabel } & \multicolumn{1}{c}{ Alpha } & Keterangan \\
\hline Tangible & 0,8 & Reliabel \\
\hline Reliability & 0,8 & Reliabel \\
\hline Resvonsiveness & 0,8 & Reliabel \\
\hline Assurance & 0,8 & Reliabel \\
\hline Empathy & 0,8 & Reliabel \\
\hline Keputusan & 0, & Reliabel \\
Konsumen & 87 & \\
\hline
\end{tabular}

Sumber : Data primer yang diolah, 2019

Hasil uji reliabilitas tersebut menunjukkan bahwa semua variabel mempunyai koefisien Alpha yang cukup besar yaitu diatas 0,6 sehingga dapat dikatakan semua konsep pengukur masing-masing variabel dari kuesioner adalah reliabel yang berarti bahwa kuesioner yang digunakan dalam penelitian ini merupakan kuesioner yang handal.

\section{Analisis Regresi Linier Berganda}

Hasil pengolahan data dengan menggunakan program SPSS selengkapnya ada pada lampiran dan selanjutnya dijelaskan pada Tabel berikut ini :

Tabel 9 Hasil Uji Regresi Linier Berganda

Unstandardized Standardized Coefficients Coefficients

\begin{tabular}{|c|c|c|c|}
\hline Model & $\mathrm{B}$ & Std. Error & Beta \\
\hline 1 (Constant) & 10,782 & 6,330 & \\
\hline Bukti Fisik (X1) &, 230 &, 147 &, 221 \\
\hline Handal (X2) &, 005 &, 159 &, 005 \\
\hline Daya Tanggap (X3) &, 334 &, 223 & ,199 \\
\hline Jaminan (X4) & ,306 &, 115 &, 303 \\
\hline Kepedulian (X5) &, 393 &, 140 &, 390 \\
\hline
\end{tabular}

Sumber: Data Primer Diolah, 2019

Model persamaan regresi yang dapat dituliskan dari hasil tersebut 
dalam bentuk persamaan regresi sebagai berikut :

$\mathrm{Y}=10,782+0,230 \mathrm{X}_{1}+0,005 \mathrm{X}_{2}+$ $0,334 \mathrm{X}_{3}+0,306 \mathrm{X}_{4}+0,393 \mathrm{X}_{5}+\mathrm{e}$

Persamaan regresi tersebut dapat dijelaskan sebagai berikut :

1. Persamaan regresi linear berganda diatas, diketahui mempunyai nilai konstanta sebesar 10,783 dengan tanda positif. Sehingga besaran konstanta menunjukan bahwa jika variabel-variabel independen yaitu bukti fisik, handal, daya tanggap jaminan dan kepedulian diasumsikan dengan nilai konstan, maka variabel dependen yaitu keputusan mahasiswa akan naik sebesar $10,783 \%$.

2. Nilai koefisien regresi $X 1$ sebesar 0,230 artinya untuk setiap kenaikan 1 skor variabel bukti fisik (X1) akan menaikkan skor Kepuasan Mahasiswa (Y) sebesar 0,230.

3. Nilai koefisien regresi $\mathrm{X} 2$ sebesar 0,005 artinya untuk setiap kenaikan 1 skor variabel handal (X2) akan menaikkan skor Kepuasan Mahasiswa (Y) sebesar 0,005

4. Nilai koefisien regresi $X 3$ sebesar 0,334 artinya untuk setiap kenaikan 1 skor variabel daya tanggap (X3) akan menaikkan skor Kepuasan Mahasiswa (Y) sebesar 0,334.

5. Nilai koefisien regresi $\mathrm{X} 4$ sebesar 0,306 artinya untuk setiap kenaikan 1 skor variabel jaminan (X4) akan menaikkan skor Kepuasan Mahasiswa (Y) sebesar 0,306.

6. Nilai koefisien regresi X5 sebesar 0,393 artinya untuk setiap kenaikan 1 skor variabel kepedulian (X5) akan menaikkan skor Kepuasan Mahasiswa (Y) sebesar 0,393.

\section{Pengujian Hipotesis}

Uji t ( Pengujian hipotesis secara parsial)

Berikut akan dijelaskan pengujian masing-masing variabel secara parsial
Variabel Bukti Fisik

Hasil pengujian diperoleh nilai $t$ untuk variabel tampilan fisik menunjukkan nilai $\mathrm{t}=1,563$ dengan nilai signifikansi sebesar $0,022<$ 0,05 . Dengan nilai signifikansi di bawah 0,05 tersebut menunjukkan bahwa bukti fisik memiliki pengaruh yang signifikan terhadap Kepuasan Mahasiswa. Hal ini berarti Hipotesis 1 diterima

\section{Variabel Kehandalan}

Hasil pengujian diperoleh nilai t untuk variabel kehandalan menunjukkan nilai $\mathrm{t}=3,063$ dengan nilai signifikansi sebesar $0,003<$ 0,05 . Dengan nilai signifikansi di bawah 0,05 tersebut menunjukkan bahwa kehandalan memiliki pengaruh yang signifikan terhadap Kepuasan Mahasiswa. Hal ini berarti Hipotesis 2 diterima.

\section{Variabel Daya Tanggap}

Hasil pengujian diperoleh nilai $t$ untuk variabel daya tanggap menunjukkan nilai $\mathrm{t}=1,500$ dengan nilai signifikansi sebesar 0,038 $<0,05$. Dengan nilai signifikansi di bawah 0,05 tersebut menunjukkan bahwa daya danggap memiliki pengaruh yang signifikan terhadap Kepuasan Mahasiswa. Hal ini berarti Hipotesis 3 diterima.

\section{Variabel Jaminan}

Hasil pengujian diperoleh nilai $\mathrm{t}$ untuk variabel jaminan menunjukkan nilai $\mathrm{t}=2,029$ dengan nilai signifikansi sebesar $0,007<0,05$. Dengan nilai signifikansi di bawah 0,05 tersebut menunjukkan bahwa jaminan memiliki pengaruh yang signifikan terhadap Kepuasan Mahasiswa. Hal ini berarti Hipotesis 4 diterima.

\section{Variabel Kepedulian}

Hasil pengujian diperoleh nilai $t$ untuk variabel kepedulian menunjukkan nilai $\mathrm{t}=1,665$ dengan nilai signifikansi sebesar 0,009 $<0,05$. 
Dengan nilai signifikansi di bawah 0,05 tersebut menunjukkan bahwa kepedulian memiliki pengaruh yang signifikan terhadap Kepuasan Mahasiswa. Hal ini berarti Hipotesis 5 diterima

\section{Uji F}

\begin{tabular}{|c|c|c|}
\hline \multirow{2}{*}{\multicolumn{3}{|c|}{$\frac{\text { Tabel } 10 \text { Has }}{\text { ANOVA }^{\mathrm{a}}}$}} \\
\hline & & \\
\hline Model & $\begin{array}{l}\text { Sum of } \\
\text { Squares df }\end{array}$ & $\begin{array}{l}\text { Mean } \\
\text { Square F }\end{array}$ \\
\hline Regression & $44,064 \quad 35$ & $6,313 \quad 2,057,001^{b}$ \\
\hline Residual & $312,722 \quad 74$ & 2,215 \\
\hline Total & $454,734 \quad 79$ & \\
\hline
\end{tabular}

Pengujian pengaruh variabel bebas secara bersama-sama terhadap variabel terikatnya dilakukan dengan menggunakan uji F. Hasil perhitungan statistik menunjukkan nilai $\mathrm{F}$ hitung $=$ 2,057 dengan signifikansi sebesar $0,002<0,05$. Dengan nilai signifikansi di bawah 0,05 menunjukkan bahwa secara bersamasama bukti fisik, keandalan, daya tanggap, jaminan, kepedulian dan kepuasan mahasiswa mempunyai pengaruh yang positif dan signifikan terhadap kepuasan mahasiswa, hal ini berarti hipotesis 6 diterima.

\section{Koefisien Determinasi}

Nilai koefisien determinasi ditentukan dengan nilai adjusted $R$ square

\section{Tabel 11 Koefisien Determinasi}

\begin{tabular}{lllll}
\hline & & & \multicolumn{3}{c}{$\begin{array}{l}\text { Std. } \\
\text { Adjusted of } \\
\text { Model }\end{array}$} & R & R Square & $\begin{array}{r}\text { R Square } \\
\text { Estimate }\end{array}$ \\
\hline 1 & $.813^{\text {a }}$ & .837 & .834 & 3.704 \\
\hline \multicolumn{4}{l}{ Sumber: Data } & Primer Diolah, 2019
\end{tabular}

Hasil perhitungan regresi dapat diketahui pada tabel di bawah ini bahwa koefisien determinasi (adjusted R2) yang diperoleh sebesar 0,834 Hal ini berarti 83,4\% Kepuasan Mahasiswa dipengaruhi oleh bukti fisik, kehandalan, daya tanggap, jaminan, kepedulian, sedangkan sisanya yaitu $16,6 \%$ kepuasan mahasiswa dipengaruhi oleh variabel-variabel lainnya yang tidak diteliti dalam penelitian ini. Hasil penelitian yang ditemukan dalam penelitian ini sejalan dengan penelitian Chandra et al. (2019) yang menemukan bahwa kualitas pelayanan merupakan aspek penting pada Perguruan tinggi yang harus di kedepankan demi memperoleh kepuasan mahasiswa.

\section{PENUTUP}

\section{Kesimpulan}

Berdasarkan pada hasil analisis regresi linier berganda yang telah dilakukan pada penelitian ini. Maka dapat ditarik kesimpulan sebagai berikut :

1. Hasil analisis diperoleh bahwa variabel bukti fisik $\left(\mathrm{X}_{1}\right)$ berpengaruh positif terhadap Kepuasan Mahasiswa (Y). Dengan demikian Hipotesis 1 yang menyatakan bahwa bukti fisik $\left(\mathrm{X}_{1}\right)$ berpengaruh positif terhadap Kepuasan Mahasiswa (Y) dapat diterima.

2. Hasil analisis diperoleh bahwa variabel kehandalan $\left(\mathrm{X}_{2}\right)$ berpengaruh positif terhadap kepuasan mahasiswa (Y). Dengan demikian Hipotesis 2 yang menyatakan bahwa kehandalan $\left(\mathrm{X}_{2}\right)$ berpengaruh positif terhadap kepuasan mahasiswa (Y) dapat diterima.

3. Hasil analisis diperoleh bahwa variabel daya tanggap $\left(\mathrm{X}_{3}\right)$ berpengaruh positif terhadap kepuasan mahasiswa (Y). Dengan demikian Hipotesis 3 yang menyatakan bahwa daya tanggap $\left(\mathrm{X}_{3}\right)$ berpengaruh positif terhadap kepuasan mahasiswa (Y) dapat diterima. 
4. Hasil analisis diperoleh bahwa variabel jaminan $\left(\mathrm{X}_{4}\right)$ berpengaruh positif terhadap kepuasan mahasiswa (Y). Dengan demikian Hipotesis 4 yang menyatakan bahwa jaminan $\left(\mathrm{X}_{4}\right)$ berpengaruh positif terhadap kepuasan mahasiswa (Y) dapat diterima.

5. Hasil analisis diperoleh bahwa variabel kepedulian $\left(\mathrm{X}_{5}\right)$ berpengaruh positif terhadap kepuasan mahasiswa (Y). Dengan demikian Hipotesis 5 yang menyatakan bahwa kepedulian $\left(\mathrm{X}_{5}\right)$ berpengaruh positif terhadap Kepuasan Mahasiswa (Y) dapat diterima.

6. Hasil analisis diperoleh bahwa variabel bebas (X) secara bersama-sama terhadap variabel terikatnya (Y) dilakukan dengan menggunakan uji $\mathrm{F}$. menunjukkan bahwa secara bersama-sama bukti fisik, keandalan, daya tanggap, jaminan dan kepedulian mempunyai pengaruh yang positif dan signifikan terhadap Kepuasan Mahasiswa, hal ini berarti hipotesis 6 dapat diterima.

7. 83,4\% Kepuasan Mahasiswa (Y) dapat dipengaruhi oleh variabel bukti fisik $\left(\mathrm{X}_{1}\right)$, kehandalan $\left(\mathrm{X}_{2}\right)$, daya tanggap $\left(\mathrm{X}_{3}\right)$, jaminan $\left(\mathrm{X}_{4}\right)$, kepedulian $\left(\mathrm{X}_{5}\right)$ dan pembagian kerja Sedangkan sisanya yaitu $16,6 \%$ kepuasan konsumen dipengaruhi oleh variabel-variabel lainnya yang tidak diteliti dalam penelitian ini.

\section{Saran}

\section{Saran Untuk Lembaga Perguruan Tinggi}

Berdasarkan kesimpulan yang diperoleh dalam penelitian ini, maka diajukan saran-saran sebagai pelengkap terhadap kualitas pelayanan yang dapat diberikan oleh Kantor STIE Prabumulih sebagai berikut:

1. STIE Prabumulih harus mengevaluasi kinerja seluruh jajaran personilnya untuk perbaikan di segala bidang, yang perlu mendapat perhatian serius adalah kepedulian karyawan kantor STIE Prabumulih terhadap kebutuhan dan keinginan mahasiswanya selanjutnya transparasi informasi prosedur pelayanan harus dikedepankan karena STIE Prabumulih adalah ujung tombak Yayasan yang berkaitan langsung dengan mahasiswa. .

2. Hasil penelitian memperlihatkan bahwa kepuasan mahasiswa dipengaruhi oleh kualitas pelayanan, oleh karena itu seluruh staf dan tata usaha STIE Prabumulih perlu meningkatkan semua faktor tersebut, sehingga tingkat kepuasan mahasiswa semakin meningkat. Pimpinan sekolah tinggi diharapkan selalu memberikan pengarahan kepada bawahannya serta mengirimkan staf/Tunya untuk mengikuti kursus dan ketrampilan yang terkait dengan pelayanan mahasiswa dalam rangka meningkatkan pelayanan pada mahasiswa sehingga kepuasan mahasiswa semakin tinggi.

3. Disarankan kepada Kantor STIE Prabumulih untuk selalu memperhatikan petugas STIE Prabumulih baik dari segi materiil maupun non materiil, karena hal ini dapat memberikan motivasi kepada petugas STIE Prabumulih, agar dapat selalu memberikan pelayanan yang berkualitas kepada mahasiswa

4. Meningkatkan citra STIE Prabumulih dengan jalan selalu dapat menyelesaikan setiap permasalahan yang dilimpahkan 
mahasiswa pada STIE Prabumulih dan selalu berada di tengah-tengah mahasiswa sebagai pengayom dan meningkatkan kesuksesan tri darma perguruan tinggi

\section{Saran Untuk Penelitian Mendatang}

Untuk penelitian selanjutnya peneliti menyarankan untuk melakukan peneltian terhadap faktorfaktor lain yang belum diteliti pada penelitian ini, yang tentunya dapat mempengaruhi variabel dependen Kepuasan Mahasiswa agar lebih melengkapi penelitian ini karena masih ada variabel-variabel independen lain di luar penelitian ini yang mungkin bisa mempengaruhi Kepuasan Mahasiswa.

\section{DAFTAR PUSTAKA}

Chandra, T., Hafni, L., Chandra, S., Purwati, A, P., Chandra, J. (2019). The influence of service quality, university image on student satisfaction and student loyalty. Benchmarking: An International Journal

Engel, F, James. (2011). Perilaku Konsumen , Jakarta: Binarupa Aksara.

Rangkuti, F. (2012). Measuring Customer Satisfaction. Jakarta: Gramedia, Pustaka Utama. Jakarta

Singarimbun, Masri. (2013). Metode Penelitian Survei. Edisi Revisi. Jakarta: LP3ES.

Tjiptono, Fandy. (2004). Manajemen Jasa. Yogyakarta: Andi Offset.

Zeithaml L, Valerie A: A Parasuraman: Leonardo L. Berry. (2012), Servqual a Multiple - Item Scale for Measuring Consumer Perception of Service Quality, Journal and Retailing, 64:12 - 40
Kotler, P. \& Keller, K.L., (2012). Marketing Manajemen 14th Edition, New Jersey: Pearson Prentice Hall.

Goetsch, David. L, \& Staanley B.Davis, (2014). Quality Management, Introduction to Total Quality Management for Production, processing, and services, New Jersey: Prentice Hall

Wilkie, W. L. (2009). Costumer Behaviour. John Willey \& Sons. 